\title{
Peningkatan Kompetensi Penyuluh Kehutanan Lingkup Sulawesi melalui Pelatihan Penyusunan Materi dan Pembuatan Media Penyuluhan Tercetak
}

\section{(The Improvement of Forestry Extension Workers' Competency in Sulawesi Areas through the Training of Material and Printed Media Preparation)}

\author{
Adi Riyanto Suprayitno \\ Balai Diklat Lingkungan Hidup dan Kehutanan Makassar, \\ Jl. Perintis Kemerdekaan Km. 17,5, Makassar 90243. \\ Penulis korespodensi: arsuprayitno@gmail.com \\ Diterima Agustus 2018/Disetujui Desember 2018
}

\begin{abstract}
ABSTRAK
Pemberdayaan masyarakat merupakan tugas dari penyuluh kehutanan. Agar kegiatan penyuluhan kehutanan dapat berjalan dengan baik dibutuhkan media sebagai alat bantu, salah satunya adalah media tercetak. Keberadaan media penyuluhan tercetak dapat memudahkan penyuluh kehutanan dalam menyebarkan informasi yang dapat mengajak petani untuk terlibat dalam kegiatan pemberdayaan masyarakat. Oleh karena itu, penguasaan kompetensi pembuatan media tercetak menjadi keharusan bagi penyuluh kehutanan. Tujuan dari kegiatan pelatihan ini adalah untuk meningkatkan pengetahuan dan keterampilan penyuluh kehutanan lingkup Sulawesi tentang penyusunan materi dan pembuatan media penyuluhan tercetak dalam bentuk brosur, leaflet, folder, dan poster. Melalui diklat penyusunan materi dan pembuatan media penyuluhan tercetak, penyuluh kehutanan diberikan bekal pengetahuan dan keterampilan cara membuat media penyuluhan tercetak. Proses pembelajaran diklat menggunakan metode brainstorming, ceramah interaktif, tanya jawab, diskusi, dan penugasan/praktik. Hasil kegiatan memperlihatkan terjadi peningkatan pengetahuan dan keterampilan peserta setelah mereka mengikuti diklat sehingga mereka mampu membuat media tercetak yang dibuktikan dengan dihasilkannya draf media tercetak yang cukup baik.
\end{abstract}

Kata kunci: media penyuluhan tercetak, pemberdayaan masyarakat, penyuluh kehutanan

\begin{abstract}
Community empowerment is the task of forestry extension workers. In order for forestry extension activities to run well, the media is needed as a tool, one of which is printed media. The existence of printed media for extension can facilitate forestry extension agents in disseminating information that can invite farmers to be involved in community empowerment activities. Therefore, mastery of the competence of making printed media is a necessity for forestry extension workers. The purpose of this training was to increase the knowledge and skills of the forestry extension workers in Sulawesi on writing materials and making extension media printed in the form of brochures, leaflets, folders, and posters. Through training in the preparation of materials and the creation of printed extension media, forestry extension workers are provided with knowledge and skills on how to make printed extension media. The training learning process uses brainstorming methods, interactive lectures, question and answer, discussion, and assignments/practices. The results of the study showed that there were increasing in participants' knowledge and skills after they attended the training which were proven by producing quite good printed media drafts.
\end{abstract}

Keywords: community empowerment, forestry extension workers, printed extension media

\section{PENDAHULUAN}

Keberadaan masyarakat yang tinggal di dalam dan sekitar kawasan hutan (MTDSH) yang pada umumnya petani, merupakan sebuah keniscayaan. Keberadaan MTDSH terhadap kawasan hutan bagaikan pisau bermata dua. Apabila perilaku MTDSH terhadap hutan bersifat negatif maka dapat menjadi ancaman bagi kelestarian kawasan hutan. Jika perilaku MTDSH positif maka dapat menjadi ujung tombak bagi kelestarian hutan.

Pada umumnya sosial ekonomi MTDSH berada dalam kondisi yang serba terbatas. 
Berdasarkan data statistik Kementerian Lingkungan Hidup dan Kehutanan (2017) tercatat bahwa terdapat sekitar 25.863 desa di hutan atau $36,7 \%$ dari desa di Indonesia. Sementara jumlah penduduk miskin di sekitar areal hutan sekitar 10,2 juta jiwa atau $36,73 \%$ dari total penduduk miskin di Indonesia. Keterbatasan kondisi ini cenderung mengarahkan MTDSH pada perilaku negatif. Upaya pemberdayaan diperlukan untuk mengentaskan masalah keterbatasan sosial ekonomi. Pemberdayaan MTDSH merupakan kunci sukses pengelolaan kawasan hutan, sekaligus dapat meningkatkan taraf sosial ekonomi MTDSH.

Kegiatan pemberdayaan MTDSH dapat dilaksanakan melalui kegiatan penyuluhan kehutanan. Pihak yang menjadi ujung tombak atau kunci keberhasilan kegiatan penyuluhan kehutanan dalam rangka memberdayakan masyarakat adalah penyuluh kehutanan. Pentingnya peran penyuluh kehutanan dikemukakan oleh Riyandoko et al. (2016) bahwa kegiatan penyuluhan pertanian, perikanan, dan kehutanan sangat berperan dalam mendidik petani mengelola usaha dan lingkungannya, bahkan di masa depan terkait dengan kegiatan kehutanan terutama agroforestry maka kebutuhan kegiatan penyuluhan kehutanan akan sangat besar. Pendapat ini sejalan dengan kebijakan pemerintah saat ini di bidang kehutanan, yaitu perhutanan sosial di mana peran serta masyarakat semakin diperhatikan, dan bahkan memberi kesempatan kepada MTDSH untuk menjadi pelaku ekonomi kehutanan. Kegiatan penyuluhan kehutanan merupakan kegiatan pendidikan non-formal untuk merubah pengetahuan, sikap, dan keterampilan MTDSH ke arah yang positif, produktif, dan kreatif agar mampu mengelola usaha taninya secara baik, bijak, dan benar sehingga dapat meningkatkan taraf hidup sekaligus terlibat aktif dalam melestarikan hutan. Kegiatan penyuluhan kehutanan terwujud dalam bentuk proses pembelajaran yang interaktif antara penyuluh kehutanan dan MTDSH. Proses pembelajaran ini membutuhkan sikap kreatif dan inovatif penyuluh kehutanan, sehingga alih teknologi dan ajakan untuk mengelola hutan secara lestari dapat tercapai.

Salah satu elemen yang merupakan bagian dari tugas pokok dan fungsi penyuluh kehutanan sebagaimana tertuang dalam PermenLHK No. 36/Menlhk-Setjen/2015, dan juga untuk tercapainya pembelajaran yang efektif dan efisien dalam kegiatan penyuluhan kehutanan adalah pembuatan dan penggunaan media penyuluhan yang sesuai dengan tujuan pembelajaran tersebut. Media penyuluhan kehutanan banyak jenis dan macamnya, dari yang paling sederhana dan murah hingga yang canggih dan mahal. Penyuluh kehutanan dituntut untuk mampu menyusun materi penyuluhan dengan baik dan mengemasnya ke dalam berbagai bentuk media penyuluhan.

Brosur, leaflet, folder, dan poster adalah bentuk media penyuluhan tercetak yang termasuk murah dalam pembuatannya dan dapat dilakukan sendiri oleh penyuluh kehutanan, namun sebagian besar penyuluh kehutanan di Sulawesi belum memiliki kemampuan yang cukup memadai untuk menyusun materi dan membuat media penyuluhan tercetak tersebut secara mandiri. Pada umumnya media tercetak yang digunakan oleh penyuluh kehutanan dalam melaksanakan tugasnya untuk mebelajarkan masyarakat bukan dibuat sendiri, melainkan buatan pihak ketiga (percetakan). Oleh karena itu, perlu untuk peningkatan kemampuan penyuluh kehutanan dalam menyusun materi dan membuat media penyuluhan tercetak. Kegiatan peningkatan kemampuan penyuluh kehutanan dalam menyusun materi dan membuat media tercetak dapat dilakukan melalui kegiatan pelatihan.

Tujuan dari kegiatan pelatihan ini adalah untuk meningkatkan pengetahuan dan keterampilan penyuluh kehutanan lingkup Sulawesi tentang penyusunan materi dan pembuatan media penyuluhan tercetak dalam bentuk brosur, leaflet, folder, dan poster. Pada kegiatan pelatihan pembuatan media tercetak ini peserta atau penyuluh kehutanan dilatih agar mampu membuat desain grafis sederhana dengan memanfaatkan fasilitas yang disediakan oleh program Microsoft Word dan Microsoft Publisher.

\section{METODE PELAKSANAAN KEGIATAN}

\section{Tempat dan Waktu}

Kegiatan pelatihan ini dilaksanakan di Balai Diklat Lingkungan Hidup dan Kehutanan Makassar. Kegiatan dilaksanakan selama delapan hari dari tanggal 3-10 April 2018 dengan jumlah jam pembelajaran 2.700 menit. Jadwal kegiatan pembelajaran diklat terlihat pada Tabel 1 .

\section{Khalayak Sasaran}

Sasaran dari kegiatan ini adalah 30 orang penyuluh kehutanan yang berasal dari instansi lingkup Pemerintah Daerah (Pemda) dan instansi 
Tabel 1 Jadwal kegiatan pembelajaran diklat

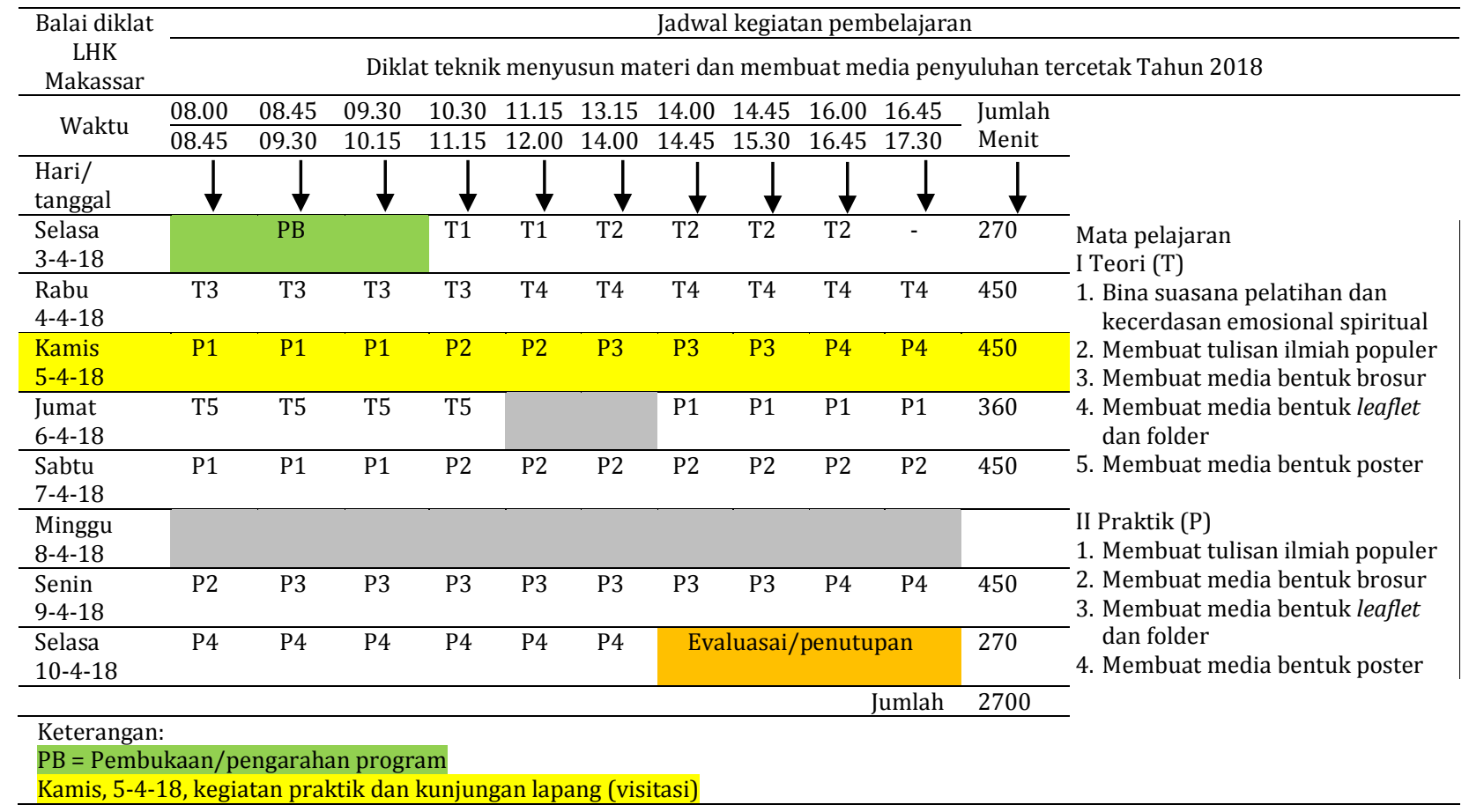

lingkup Kementerian Lingkungan Hidup dan Kehutanan (LHK) yang berada di wilayah Sulawesi.

\section{Alat dan Bahan}

Alat yang digunakan selama proses pembelajaran adalah laptop, LCD, spidol, kertas flipchart, papan flipchart, whiteboard, printer Canon IP2700, dan Canon G1000. Bahan utama yang digunakan untuk pencetakan media adalah kertas HVS ukuran folio dan A4, steples, dan art paper/kertas kundruks (kertas berwarna putih yang agak mengkilat pada kedua sisinya).

\section{Metode Pelaksanaan Pelatihan}

Proses pembelajaran dalam pelatihan ini menggunakan kombinasi berbagai metode pembelajaran orang dewasa yang sifatnya partisipatif, yaitu brainstorming, ceramah interaktif, tanya jawab, diskusi, dan penugasan/praktik. Kegiatan pelatihan dilakukan baik melalui pemberian materi berupa teori maupun praktik. Teori dan praktik dilakukan secara terintegrasi agar terjadi kesinambungan pemahaman peserta diklat terhadap materi yang disampaikan. Evaluasi dilakukan untuk menggetahui sejauh mana peningkatan kemampuan dan pemahaman peserta sebelum pelatihan (pre test) dan setelah pelatihan (post test) serta evaluasi terhadap hasil kerja peserta. Tahapan kegiatan pelaksanaan pelatihan adalah sebagai berikut: 1) Registrasi dan penampungan peserta pelatihan (penyuluh kehutanan) yang berasal dari berbagai instansi Pemda dan instansi Kementerian LHK lingkup Sulawesi; 2) Pembukaan pelatihan dan arahan umum dari penanggung jawab pelatihan kepada peserta pelatihan berkaitan dengan tujuan pelatihan; 3) Pelaksanaan pelatihan, berlangsungnya proses pembelajaran yang interaktif meliputi bina suasana pelatihan dan kecerdasan emosional spiritual, teori maupun praktik teknik penyusunan tulisan ilmiah populer yang dituangkan ke dalam berbagai media tercetak berupa brosur, leaflet, folder, dan poster; dan 4) Penutupan pelatihan.

\section{HASIL DAN PEMBAHASAN}

Kompetensi adalah karakteristik dan kemampuan kerja yang mencakup aspek pengetahuan, keterampilan, dan sikap sesuai tugas dan/atau fungsi jabatan (BKN 2013). Azmy (2015) menyatakan bahwa kompetensi adalah karakteristik yang dimiliki individu berupa kemampuan yang digunakan dengan cara yang konsisten dan sesuai untuk mencapai kinerja yang diinginkan. Pranata et al. (2018) mengartikan kompetensi sebagai kemampuan seseorang yang dapat terobservasi yang mencakup pengetahuan, keterampilan, dan sikap dalam menyelesaikan suatu pekerjaan atau tugas sesuai dengan unjuk kerja yang ditetapkan. Dari pengertianpengertian tersebut, dapat disimpulkan bahwa 
untuk melakukan suatu pekerjaan yang berkaitan dengan jabatan tertentu memerlukan beberapa pengetahuan dan keterampilan yang secara sengaja harus dipelajari dan kemudian diaplikasikan bagi kepentingan umum

Diklat menyusun materi dan membuat media penyuluh kehutanan tercetak merupakan sebuah kegiatan pembelajaran untuk membekali penyuluh kehutanan dengan kompetensi pembuatan media penyuluhan tercetak. Media penyuluhan merupakan salah satu aspek penting dalam kegiatan peyuluhan yang dapat memudahkan penyuluh kehutanan dalam melaksanakan tugasnya sebagai pemberdaya masyarakat. Proses pembelajaran dilaksanakan dengan mengacu pada konsep "experiental learning". Experiential learning adalah suatu pendekatan yang berpusat pada subyek didik, yaitu peserta diklat. Landasan pemikiran experiental learning adalah bahwa individu akan belajar terbaik melalui pengalaman (Walter \& Mark 1981). Oleh karena itu, di dalam proses pembelajaran, ditekankan pada bagaimana membawa peserta diklat pada situasi nyata, yaitu dengan cara leaning by doing (belajar sambil mengerjakan). Kegiatan atau materi yang diberikan pada proses pembelajaran dalam diklat ini meliputi:

\section{- Bina suasana pelatihan dan kecerdasan emosional spritual}

Sesuai dengan namanya bina suasana pelatihan dan kecerdasan emosional spritual bertujuan untuk membangun iklim pembelajaran yang kondusif, membina iklim kepercayaan, iklim kebersamaan antara peserta yang berasal dari berbagai daerah agar terjadi keakraban antara peserta di dalam mengikuti proses pembelajaran dengan mengedepankan keseimbangan emosi dan spiritual. Situasi kondusif terbangun jika barrier komunikasi telah tereduksi, unsur kepercayaan (trust) telah terbangun. Rahmat (2002) menyatakan bahwa trust merupakan landasan awal untuk berhubungan lebih jauh. Yuliawan (2014) menyatakan kepercayaan diperoleh melalui proses membangun rapor (keakraban) yang baik.

Kegiatan ini dilaksanakan di awal pelatihan setelah pembukaan selama 90 menit (sebagaimana jadwal kegiatan pembelajaran diklat pada Tabel 1). Substansi kegiatan ini ditekankan pada membangun hubungan (building rapport) dan pembekalan mental yang dilaksanakan melalui kegiatan permainan (game), refleksi, dan diskusi singkat. Kegiatan ini merupakan pintu masuk atau pra-kondisi bagi kelancaran kegiatan pembelajaran selanjutnya. Melalui kegiatan ini peserta dimotivasi dan dibekali dengan nilai-nilai emosional spiritual agar bersemangat dalam mengikuti pembelajaran dan dapat memanfaatkan pengetahuan yang diperoleh demi kepentingan masyarakat. Suasana pelatihan terlihat pada Gambar 1.

Permainan dimulai dengan pengenalan terhadap diri sendiri dan dilanjutkan dengan pengenalan antar-peserta. Melalui permainan pengenalan terhadap diri sendiri, peserta diajak melakukan refleksi tentang siapa dirinya, apa karakter dirinya, apa tujuan hidupnya, apa kelemahan dirinya, dan apa kekuatan dirinya, serta bagaimana sikap mereka ketika berhubungan dengan orang lain.

Pengenalan terhadap orang lain dilakukan dengan cara membentuk kelompok-kelompok kecil di mana setiap kelompok terdiri dari enam anggota. Permainan dilakukan dengan cara anggota dalam setiap kelompok kecil saling berkenalan, selanjutnya satu per satu diminta untuk tampil memperkenalkan teman dalam kelompoknya kepada kelompok lain. Kegiatan ini dilakukan bergantian oleh setiap kelompok.

Setelah perkenalan, untuk lebih mengakrabkan antara peserta dilakukan permainan membangun sikap kerja sama. Permainan ini dilakukan oleh setiap kelompok. Setiap kelompok diberi tugas untuk membuat cerita terkait dengan media tercetak. Cerita tersebut harus ditulis pada flip chart yang telah disiapkan di mana setiap peserta (anggota kelompok) secara bergiliran maju ke depan untuk menulis satu kata sehingga nantinya membentuk sebuah cerita utuh. Setiap anggota kelompok bisa membisikkan atau memberikan kepada teman kelompoknya kata yang ingin dipilih dan ditulis.

Pada akhir kegiatan, secara demokratis, peserta diminta untuk menyusun kepengurusan pewakilan peserta yang dikenal dengan Dewan

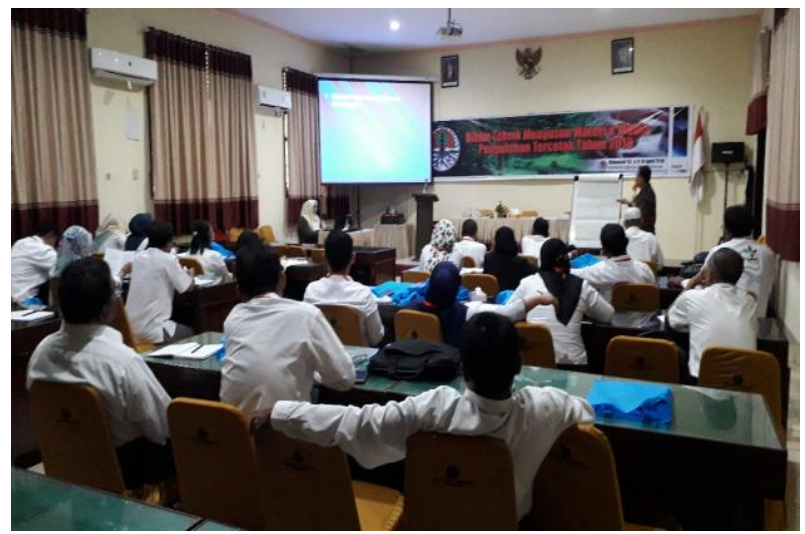

Gambar 1 Suasana pelatihan. 
Perwakilan Peserta yang terdiri dari ketua, sekretaris, dan seksi kesiswaan/pengajaran.

\section{- Pelatihan membuat tulisan ilmiah populer}

Menuangkan informasi ke dalam media tercetak membutuhkan kemampuan menulis yang baik. Oleh karena itu, penyuluh kehutanan dituntut memiliki kemampuan tersebut. Dengan adanya kemampuan menulis yang baik maka penyuluh kehutanan diharapkan mampu membuat tulisan yang dapat mengajak, membimbing, dan menyampaikan informasi kepada masyarakat agar masyarakat tahu, mau dan mampu melakukan perubahan ke arah yang lebih baik.

Sasaran penyuluhan kehutanan adalah masyarakat sekitar hutan atau masyarakat awam yang rata-rata taraf pendidikannya adalah SMP, oleh karena itu, informasi atau ide yang dituliskan harus dapat dipahami dengan mudah oleh masyarakat. Untuk mempermudah sasaran memahami tulisan maka perlu dikemas dalam bentuk tulisan ilmiah popular. Materi pembelajaran tulisan ilmiah popular yang disampaikan dalam proses pembelajaran meliputi pengertian tulisan ilmiah populer, tujuan penyusunan tulisan ilmiah populer, teknik menyusun kalimat, dan membuat paragraf sehingga menjadi sebuah karangan atau tulisan ilmiah popular yang utuh, padu, dan efektif.

Sebagian besar peserta di awal pembelajaran mengakui bahwa mereka memiliki banyak ide tetapi mengalami kesulitan ketika akan dituangkan dalam bentuk tulisan. Oleh karena itu, materi pembelajaran yang disampaikan lebih menekankan pada kegiatan penugasan dalam bentuk praktik menulis. Kegiatan pembelajaran mata pelatihan ini dilaksanakan selama 630 menit yang terdiri dari 180 menit teori dan 450 menit praktik (sebagaimana jadwal kegiatan pembelajaran diklat pada Tabel 1). Kegiatan pembelajaran dimulai dengan memberikan tugas atau latihan sederhana kepada peserta pelatihan. Peserta diminta menceritakan pengalaman perjalanan atau kejadian yang dialami dimulai dari tempat asal peserta sampai tiba di Makassar dan saat pelatihan dalam bentuk karangan singkat. Berdasarkan tulisan ini dapat diketahui kemampuan awal peserta dalam membuat tulisan (karangan).

Setelah peserta membuat tulisan singkat, kemudian peserta diminta pendapatnya melalui brainstorming (curah pendapat) tentang kesulitan atau masalah ketika berusaha membuat tulisan. Melalui metode brainstorming peserta diminta untuk mengekspresikan gagasan atau pendapatnya terkait dengan kesulitan atau masalah yang dihadapi dalam rangka mencari solusi atas masalah tersebut. Roestiyah (2013) menyatakan bahwa teknik mengajar dengan metode brainstorming adalah melontarkan masalah kepada peserta kemudian peserta menyatakan pendapat atau memberi komentar atas masalah tersebut. Suparman (2010) menyatakan bahwa metode brainstorming merupakan upaya untuk mengumpulkan pendapat atau ide dalam rangka mencari solusi atas masalah yang dihadapi.

Setelah peserta dibimbing dan berlatih menulis melalui kegiatan ceramah, tanya jawab, dan penugasan. Peserta diminta untuk melihat kembali draf karangan atau tugas yang sebelumnya telah ditulis untuk melihat kesalahan-kesalahan yang dibuat dalam tulisan tersebut jika dibandingkan dengan kaidah-kaidah penulisan yang mereka telah peroleh melalui kegiatan pembelajaran. Melalui proses pembandingan ini peserta menjadi lebih tahu, lebih paham cara menuangkan gagasan ke dalam bentuk tulisan/ karangan.

\section{- Pelatihan membuat brosur}

Setelah peserta berlatih membuat karangan singkat, selanjutnya mereka diminta menyusun sebuah tulisan ilmiah popular yang akan dituangkan ke dalam media tercetak brosur. Brosur dalam kegiatan penyuluhah kehutanan sering juga disebut booklet, merupakan sebuah buku yang ukurannya tidak terlalu besar. Ukuran brosur 13,5 x $18 \mathrm{~cm}$ atau ukuran lain yang dapat dikategorikan sebagai buku. Lembaran halaman tidak terlalu banyak minimal 12 halaman dan maksimal 40 halaman bolak-balik.

Kegiatan pelatihan ini dilaksanakan selama 630 menit yang terdiri dari 90 menit untuk teori dan 450 menit untuk praktik (sebagaimana jadwal kegiatan pembelajaran diklat pada Tabel 1). Materi yang disampaikan kepada peserta pelatihan melaui metode ceramah interaktif dan tanya jawab meliputi pengertian, tujuan dan manfaat, cara memilih dan menetapkan paket materi, cara merancang penyusunan naskah, dan cara membuat media bentuk brosur. Peserta dibimbing dan dilatih membuat brosur dengan cara sederhana, yaitu memanfaat fasilitas booklet yang tersedia dalam MS. Word. Aplikasi MS. Word dipilih karena mudah mengoperasikannya dan sudah sangat dikenal serta sering digunakan oleh penyuluh kehutanan, namun semua peserta pelatihan belum mengetahui cara memanfaatkan fasilitas booklet yang terdapat dalam MS. Word. 
Peserta dilatih membuat brosur dengan langkah-langka sederhana, yaitu dimulai dengan membuat layout dan menulis naskah. Peserta diminta untuk memilih menu "page setup", selanjutnya memilih ukuran kertas. Setelah itu, peserta diminta untuk mengatur margin kertas. Selanjutnya memilih "bookfold" yang terdapat dalam menu "multiple pages". Pada menu "sheet per bloked" peserta diminta memilih "all", maka orientasi akan berubah secara otomatis dari potrait menjadi landscape, dengan demikian layout brosur sudah terbentuk. Setelah layout terbentuk maka draf naskah yang telah ditulis dituangkan ke dalam layout tersebut. Selanjutnya peserta dilatih untuk mencetak brosur yang telah dibuat menggunakan printer berwarna Canon IP2700 dan Canon G1000. Setelah peserta mendapatkan teori, selanjutnya diberi tugas untuk membuat brosur. Slameto (2014) menyatakan bahwa memberikan tugas kepada peserta didik berarti memberi kesempatan untuk mempraktikan keterampilan yang baru saja didapatkan. Sudirman (2011) menyatakan bahwa metode penugasan sangat penting diterapkan dalam proses pembelajaran karena dapat membantu dan memotivasi peserta dalam memperoleh pengetahuan dan keterampilan baru.

\section{- Pelatihan membuat leaflet dan folder}

Proses pembelajaran membuat leaflet dan folder dilaksanakan selama 720 menit yang terdiri dari 270 menit untuk teori dan 450 menit untuk praktik sebagaimana jadwal kegiatan pembelajaran diklat pada Tabel 1. Pertama-tama melalui metode ceramah interaktif disampaikan kepada peserta pelatihan pengetahuan tentang perbedaan folder dan leaflet dalam konteks penyuluhan kehutanan. Hal ini perlu disampaikan karena selama ini terjadi kesalahan persepsi tentang kedua bentuk media tercetak ini. Kebanyakan peserta menganggap bahwa leafleat dan folder adalah sama.

Setelah mendapat penjelasan tentang pengertian leaflet dan folder melalui ceramah inteaktif dan tanya jawab, selanjutnya peserta ditugaskan secara mandiri untuk memilih tema dan membuat karangan singkat yang akan dituangkan ke dalam bentuk leaflet dan folder. Pemilihan dan penetapan tema dilakukan dengan cara brainstorming. Setelah ditemukan tema, kemudian peserta dibimbing untuk memanfaatkan fasilitas membuat folder dan leaflet yang sudah tersedia pada MS. Word. Selain memanfaatkan fasilitas pembuatan folder dan leaflet yang sudah ter- pasang pada $M S$. Word, masih menggunakan $M S$. Word, peserta dilatih dan dibimbing untuk membuat layout folder secara manual dengan memanfaatkan menu colom. Peserta pelatihan juga dibimbing menggunakan MS. Publisher untuk membuat leaflet dan folder sebagai alternatif pengganti MS. Word. MS. Publisher memiliki fasilitas pembuatan leaflet dan folder yang lebih lengkap dibandingkan MS. Word.

\section{- Pelatihan membuat poster}

Untuk menggugah kesadaran masyarakat terhadap adanya sebuah program pembangunan sehingga diharapkan masyarakat menjadi tahu dan tertarik untuk terlibat dalam program pembangunan, maka poster dapat menjadi salah satu alternatif media penyuluhan. Artinya, poster dalam kegiatan penyuluhan berfungsi sebagai media publikasi agar masyarakat bisa membacanya dan melakukan sesuatu sesuai dengan apa yang ada dalam poster tersebut.

Dalam diklat ini, peserta diklat dibimbing untuk membuat dan merancang (desain grafis) poster sederhana. Peserta diklat dibimbing untuk merancang komposisi poster yang terdiri atas huruf dan gambar di atas media kertas untuk kemudian apabila akan digunakan dapat ditransfer ke kain yang berukuran besar. Proses pembelajaran berlangsung selama 630 menit yang terdiri dari 180 menit untuk teori dan 450 menit untuk praktik (sebagaimana jadwal kegiatan pembelajaran diklat pada Tabel 1). Peserta dibimbing membuat poster dengan menggunakan fasilitas yang disediakan oleh MS. Office yaitu MS. Publisher. MS. Publisher menyediakan banyak template untuk pembuatan poster. Alasan digunakannya fasilitas MS. Publisher karena peserta lebih familiar dengan MS. Office dan mudah dalam pengoperasiannya. Setelah mendapatkan bimbingan cara sederhana membuat poster, setiap peserta diberi tugas untuk membuat konsep poster sesuai dengan tema yang mereka pilih.

Peserta diajak megunjungi (visitasi) ke salah satu kantor penerbit media tercetak, yaitu kantor redaksi harian dan TV Fajar untuk lebih melengkapi pengetahuan peserta diklat tentang media penyuluhan tercetak. Pada kunjungan ini dilakukan diskusi dan tanya jawab dengan pimpinan redaksi harian fajar terkait dengan proses pembuatan media tercetak mulai dari pemilihan topik, peliputan, pemilahan, dan pemilihan berita sampai dengan proses pencetakan untuk kemudian didistribusikan ke masyarakat. 
Tingkat Kemampuan Awal Sasaran tentang Peyusunan Materi dan Pembuatan Media Penyuluhan Kehutanan Tercetak

Peserta diberi kuesioner (pre-test) untuk mengetahui kompetensi awal sasaran/peserta terkait dengan materi yang disampaikan pada diklat penyusunan materi dan pembuatan media penyuluhan tercetak yang meliputi penyusunan tulisan ilmiah popular, pembuatan brosur, pembuatan folder, pembuatan leaflet, dan pembuatan poster. Moekijat (2009) menyatakan bahwa informasi yang diperoleh melalui pre-test dapat membantu memperbaiki program pembelajaran. Melalui pre-test diperoleh hasil seperti pada Gambar 2.

Kemampuan awal peserta sebelum mengikuti diklat terhadap materi pembuatan tulisan ilmiah popular (TIP), pembuatan brosur, folder, leaflet, dan poster masuk dalam kategori rendah. Kondisi tersebut tercermin pada sebaran jawaban peserta diklat, yaitu $70 \%$ peserta diklat menyatakan belum mampu membuat tulisan ilmiah popular, 66,67\% menyatakan belum mampu membuat brosur, sementara itu untuk teknik membuat folder sebanyak $76,67 \%$ peserta diklat menyatakan belum mampu, selanjutnya $60 \%$ peserta diklat menyatakan belum mampu membuat leaflet, dan $80 \%$ peserta diklat menyatakan belum memiliki kemampuan membuat poster.

Mengacu pada kondisi tersebut, diklat penyusunan materi dan pembuatan media penyuluhan kehutanan tercetak sangat tepat untuk diikuti oleh penyuluh kehutanan sehingga diharapkan mampu menunjang kegiatan penyuluhan ke- hutanan atau pemberdayaan masyarakat yang sejatinya menjadi tugas pokok para penyuluh kehutanan.

\section{Tingkat Kemampuan Sasaran Setelah Mengikuti Proses Pembelajaran Penyusunan Materi dan Pembuatan Media Penyuluhan Kehutanan Tercetak}

Selama mengikuti proses belajar mengajar selama kurang lebih delapan hari dari tanggal 310 April 2018, yang mana dalam proses tersebut berlangsung interaksi dinamis antara peserta diklat dengan widyaiswara (pengajar), dilakukan penilaian terhadap tingkat pengetahuan dan keterampilan peserta diklat. Penilaian dilaksanakan dalam bentuk pengamatan selama proses bimbingan yang hasilnya termanifestasi dalam wujud fisik, yaitu tulisan ilmiah popular yang dituangkan ke dalam beberapa media penyuluhan tercetak brosur/booklet, leaflet, dan folder serta poster. Selain itu, kepada peserta diklat diberikan angket (post-test). Moekijat (2009) menyatakan bahwa melalui post-test dapat diperoleh informasi terkait dengan peningkatan pemahaman peserta didik terhadap mata ajaran yang dipelajari. Kajian perkembangan tingkat pengetahuan dan keterampilan peserta diklat disajikan dalam Gambar 3.

Hasil kegiatan menunjukkan setelah mengikuti proses pembelajaran selama delapan hari terjadi peningkatan pengetahuan dan keterampilan peserta diklat. Kemampuan sebagian besar peserta diklat, berada dalam kategori mampu sampai dengan sangat mampu untuk menyusun

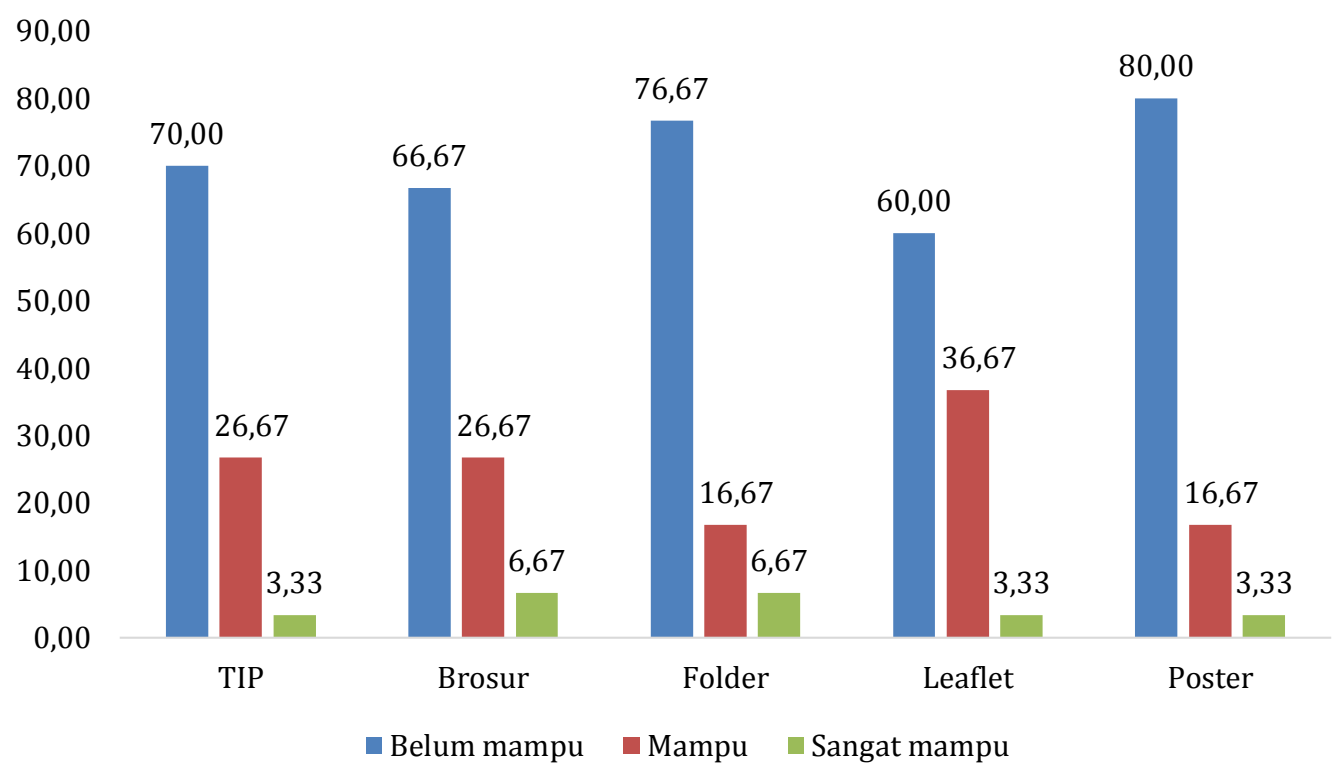

Gambar 2 Sebaran kompetensi peserta sebelum mengikuti diklat. 
tulisan ilmiah popular (TIP). TIP ini selajutnya dituangkan ke dalam media tercetak brosur, folder, leaflet, dan poster. Gambar 3 memperlihatkan sebaran jawaban peserta diklat, yaitu $73,33 \%$ peserta diklat menyatakan sangat mampu membuat tulisan ilmiah popular, $76,67 \%$ menyatakan sangat mampu membuat brosur, sementara itu untuk teknik membuat folder sebanyak $83,63 \%$ peserta diklat menyatakan sangat mampu, $80 \%$ peserta diklat menyatakan sangat mampu membuat leaflet, dan $80 \%$ peserta diklat menyatakan sangat memiliki kemampuan membuat poster.

Peningkatan kemampuan peserta diklat, yaitu kemampuan menyusun tulisan ilmiah popular, brosur, folder dan leaflet, dan poster diharapkan akan dapat meningkatkan kreativitas penyuluh kehutanan dalam menjalankan tugasnya sebagai agen pem-baharu untuk mendidik dan memberdayakan masyarakat setelah mereka kembali ke wilayah kerjanya masing-masing.

\section{Peningkatan Kemampuan Sasaran Tentang Penyusunan Materi dan Pembuatan Media Penyuluhan Kehutanan Tercetak}

Jika setiap mata pelajaran disandingkan dan dibandingkan antara sebelum dan sesudah mengikuti diklat, maka terlihat adanya peningkatan kompetensi (Gambar 4). Terjadi peningkatan jumlah peserta yang sangat mampu menulis tulisan ilmiah popular yaitu sekitar $70 \%$. Hal ini terlihat dari hasil kajian peserta yang sangat

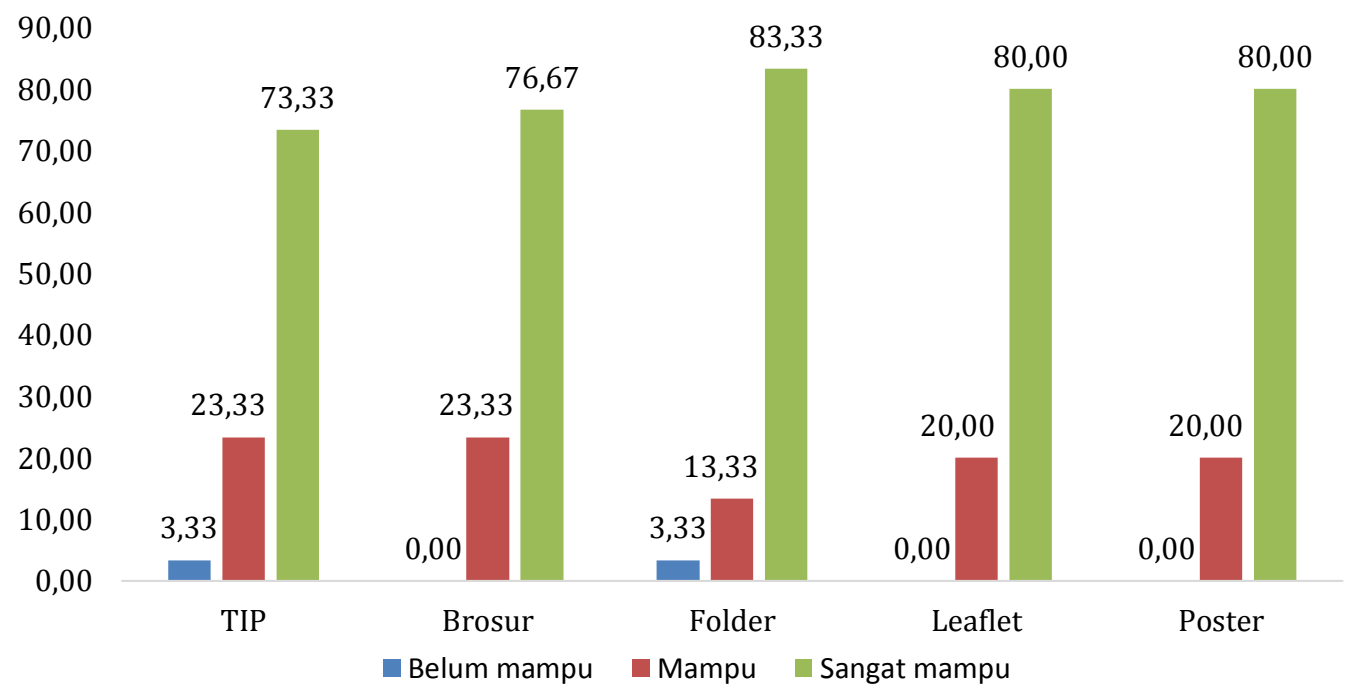

Gambar 3 Sebaran kompetensi peserta setelah mengikuti diklat.

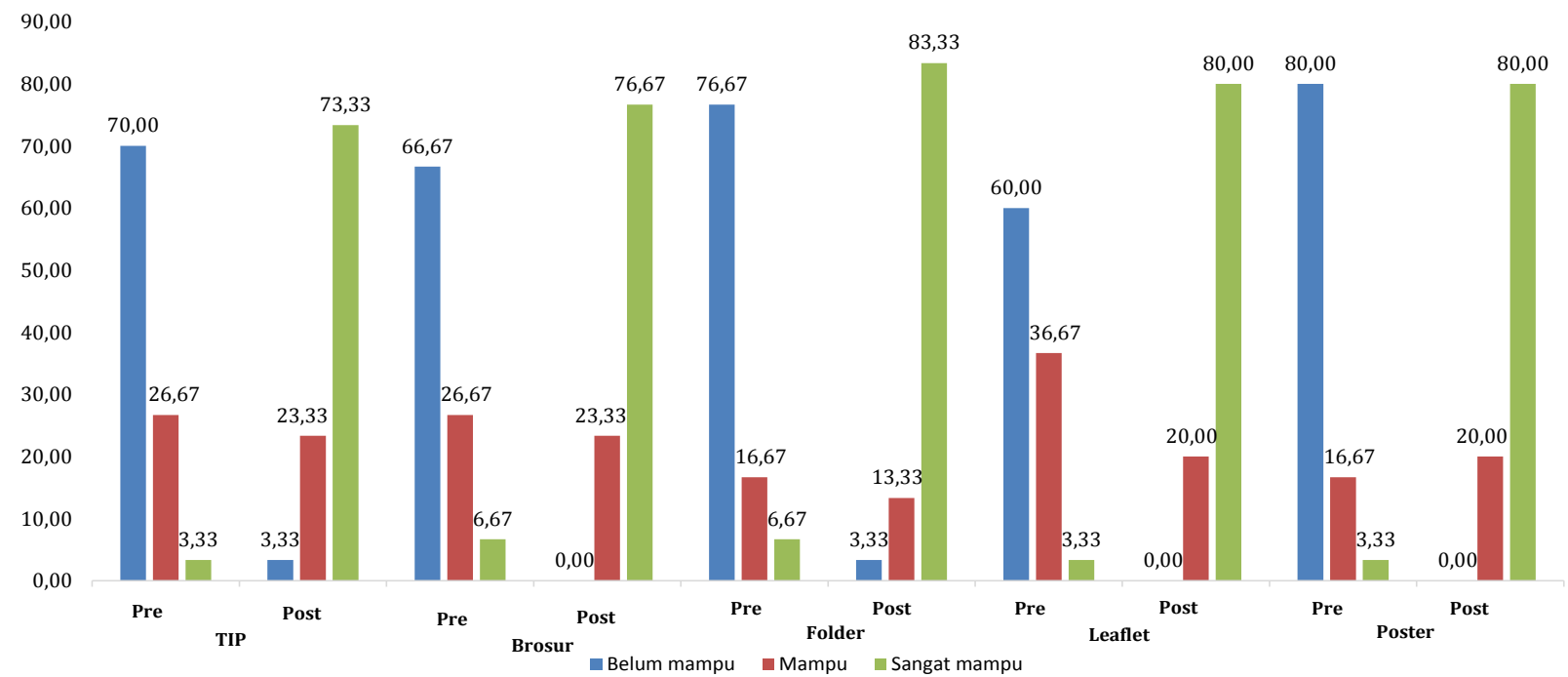

Gambar 4 Perbandingan sebaran kompetensi peserta antara sebelum dan sesudah mengikuti diklat. 
mampu membuat tulisan ilmiah popular setelah mengikuti diklat menjadi $73,33 \%$ peserta yang sangat mampu membuat tulisan ilmiah popular.

Jumlah peserta yang meningkat kompetensinya dalam membuat media cetak brosur sekitar 70\%. Kondisi ini dapat dilihat pada Gambar 4 bahwa sebelum mengikuti proses pembelajaran hanya $6,67 \%$ peserta yang sangat mampu, namun setelah mengkuti pembelajaran jumlah peserta yang sangat mampu dalam membuat brosur menjadi $76,67 \%$. Jumlah peserta yang kompeten dalam membuat folder juga meningkat, pada awalnya hanya $6,67 \%$ peserta yang sangat mampu membuat folder meningkat menjadi $83,33 \%$ peserta. Hal ini berarti terjadi peningkatan sekitar $76,66 \%$ jumlah peserta yang sangat mampu membuat folder.

Kompetensi peserta dalam membuat leaflet dan poster juga terjadi peningkatan, yaitu sekitar $76,67 \%$. Terjadi peningkatan jumlah peserta yang sangat mampu dalam membuat leaflet dan poster, di mana sebelum mengikuti diklat hanya sekitar 3,33\% setelah mengikuti diklat jumlah peserta yang sangat mampu meningkat menjadi $80 \%$.

Hasil nyata dari peningkatan kompetensi peserta sebagai hasil proses pembelajaran diklat dibuktikan dalam bentuk produk/hasil praktik berupa draf media tercetak. Setiap peserta diminta menghasilkan 4 draf media tercetak. Gambar 5 menunjukkan sebagian draf media tercetak hasil praktik peserta diklat.

\section{SIMPULAN}

Diklat penyusunan materi dan pembuatan media penyuluhan tercetak yang dilaksanakan oleh Balai Diklat Lingkungan Hidup dan Kehutanan Makassar selama delapan hari, yaitu dari tanggal 3-10 April 2018 telah berhasil meningkatkan kemampuan peserta diklat (penyuluh kehutanan) dari mampu sampai dengan sangat mampu. Hasil kajian memperlihatkan bahwa tingkat keberhasilan peserta diklat ratarata di atas $70 \%$ yang kemudian dibuktikan dengan hasil kerja mereka berupa draf media cetak dalam bentuk leaflet, folder, brosur, dan miniatur poster. Kondisi ini mencerminkan bahwa program diklat berhasil membantu dan memotivasi penyuluh kehutanan untuk mampu kreatif membuat berbagai media penyuluhan yang dapat digunakan untuk menunjang keberhasilan kegiatan penyuluhan kehutanan atau

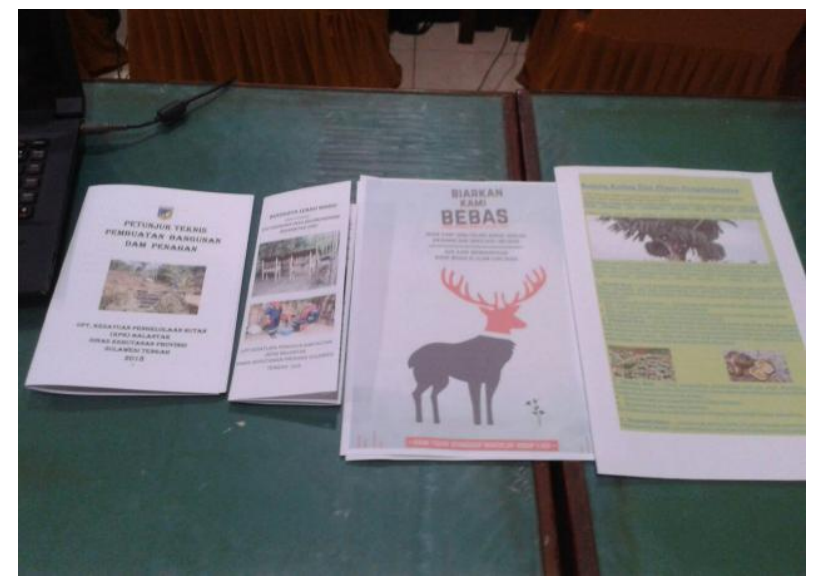

Gambar 5 Draf media tercetak hasil praktik peserta diklat.

pemberdayaan masyarakat. Keterampilan membuat media tercetak dapat lebih memampukan penyuluh dalam meningkatkan kinerjanya. Keterampilan membuat media tercetak memiliki kontribusi terhadap peningkatan karier penyuluh kehutanan karena keterampilan membuat media tercetak, yang dibuktikan dengan adanya bukti fisik media tercetak tersebut, merupakan salah satu dari unsur penilaian kinerja penyuluh kehutanan dalam membantu dan memberdayakan masyarakat sekitar hutan. Selain itu, agar penyuluh kehutanan dapat melaksanakan tugas dan tanggung jawabnya secara profesional maka menjadi keharusan bagi setiap penyuluh kehutanan untuk meningkatkan kompetensinya secara terus-menerus.

\section{DAFTAR PUSTAKA}

Azmy A. 2015. Pengembangan Kompetensi Sumber Daya Manusia Untuk Mencapai Career Ready Professional di Universitas Tanri Abeng. Binus Busines Review. 6(2): 220-232. https://doi.org/10.21512/bbr.v6i2.971

[BKN] Badan Kepegawaian Negara. 2013. Peraturan Kepala Badan Kepegawaian Negara Nomor: 7 Tahun 2013 tentang Pedoman Penyusunan Standar Kompetensi Manajerial Pegawai Negeri Sipil. Jakarta (ID): Badan Kepegawaian Negara.

[Kemen LHK] Kementerian LIngkungan Hidup dan Kehutanan. 2017. Perhutanan Sosial, Membangun Kemakmuran Desa. [Internet]. Diakses pada Mei 2017. Tersedia pada: http://www.menlhk.go.id/berita-281erhutanan-sosial-membangun kemakmurandari-desa.html. 
[Kemen LHK]. Kementerian Lingkungan Hidup dan Kehutanan. 2015. Peraturan Menteri Lingkungan Hidup dan Kehutanan Nomor 3/MenLHK-Setjen/2015 tentang Petunjuk Teknis Jabatan Penyuluh Kehutanandan Angka Kreditnya. Jakarta (ID): KemenLHK.

Moekijat. 2009. Evaluasi Pelatihan Dalam Rangka Meningkatkan Produktivitas Perusahaan. Bandung (ID): Mandar Maju.

Pranata OS, Astuti ES, Utami HN. 2018. Pengaruh Pelatihan Terhadap Kompetensi Dan Kinerja Karyawan (Studi Pada Karyawan Tetap di PT Bank Tabungan Pensiunan Nasional Syariah Malang Divisi Mobile Marketing Syariah). Jurnal Administrasi Bisnis (JAB). 61(3): 39-47.

Rahmat J. 2002. Psikologi Komunikasi. Bandung (ID): Remaja Rosda Karya.

Riyandoko, Martini E, Perdana A, Yumn A, Roshetko JM. 2016. Situasi Terkini, Tantangan dan Kebutuhan Pelaksanaan Penyuluhan Kehutanan dan Agroforestri di Indonesia. Bogor (ID): ICRAF.

Roestiyah NK. 2013. Strategi Belajar Mengajar. Jakarta (ID): Rineka Cipta.

Slameto. 2014. Belajar dan Faktor-Faktor yang Memengaruhinya. Jakarta (ID): Rineka Cipta.

Sudirman. 2011. Ilmu Pendidikan. Bandung (ID): Remaja Rosda Karya.

Suparman A. 2010. Model-Model Pembelajaran Interaktif. Jakarta (ID): LAN-RI.

Walter GA, Mark SE. 1981. Experiential Learning and Change: Theory, Design and Practice. New York (US): Wiley.

Yuliawan TP. 2014. NLP: The Art of Enjoying Life. Jakarta (ID): Serambi Ilmu Semesta. 